\title{
TIMP2 gene polymorphism as a potential tool to infer Brazilian population origin
}

\author{
This article was published in the following Dove Press journal: \\ Advances in Genomics and Genetics \\ 5 December 2013 \\ Number of times this article has been viewed
}

\author{
Rodrigo Augusto da Silva' \\ André Luis Shinohara ${ }^{2}$ \\ Denise Carleto Andia' \\ Ariadne Letra ${ }^{3}$ \\ Regina Célia Peres' \\ Ana Paula de Souza' \\ 'Department of Morphology, \\ Piracicaba Dental School, \\ State University of Campinas, \\ ${ }^{2}$ Oral Biology Program, Bauru \\ Dental School, State University \\ of São Paulo, São Paulo, Brazil; \\ ${ }^{3}$ Department of Endodontics and \\ Center for Craniofacial Research, \\ School of Dentistry, University \\ of Texas Health Science Center, \\ Houston, TX, USA
}

\begin{abstract}
Single nucleotide polymorphisms are genome variations that can be used as population-specific markers to infer genetic background and population origin. The Brazilian population is highly admixed due to immigration from several other populations. In particular, the state of São Paulo is recognized for the presence of Japanese individuals who seem likely to have contributed to a substantial proportion of ancestry in the modern Brazilian population. In the present study, we analyzed allele and genotype frequencies and associations of the $-418 \mathrm{G}>\mathrm{C}$ (rs8179090) single nucleotide polymorphism in the TIMP2 gene promoter in Brazilian and Japanese subjects, as well as in Japanese descendants from southeastern Brazil. The allele and genotype frequency analyses among groups demonstrated statistical significance $(P<0.001)$ and the rare $\mathrm{C}$ allele was not found in 200 unrelated Brazilian subjects, while its distribution in Japanese individuals and Japanese descendants was $18.7 \%$ and $10.3 \%$, respectively. Individuals with the $\mathrm{C}$ allele were about 70 times more likely to be Japanese and 41 times more likely to be Japanese descendants compared with Brazilian individuals (odds ratio 69.09 , 95\% confidence interval $9.35-510$ for Japanese; and odds ratio 41.38, 95\% confidence interval 4.80-356.15 for Japanese descendants). Taken together, these findings suggest that subjects carrying the $\mathrm{C}$ allele, located in the $-418 \mathrm{G}>\mathrm{C}$ single nucleotide polymorphism of the TIMP2 gene, have a high probability of being Japanese or Japanese descendants. In addition to other genetic polymorphisms, the $-418 \mathrm{G}>\mathrm{C}$ TIMP2 polymorphism could be a population marker to assist in predicting Japanese ancestry, both in Japanese individuals and in admixed populations.
\end{abstract}

Keywords: Brazilian, Japanese, polymorphism, allele, TIMP2

\section{Introduction}

Single nucleotide polymorphisms (SNPs) are genome variations that occur with a frequency of at least $1 \%$ in a given population. The estimated incidence is approximately one SNP per 1,000 bases in the overall human population, leading to millions of SNPs. ${ }^{1}$ The $-418 \mathrm{G}>\mathrm{C}$ (rs8179090) polymorphism is located in the promoter region of the tissue inhibitor of the matrix metalloproteinase (TIMP2) gene and was first described by Hirano et al. ${ }^{2}$ These authors investigated patients with chronic obstructive pulmonary disease and demonstrated an association between the recently discovered polymorphism, $-418 \mathrm{G}>\mathrm{C}$, and the disease. During the last 10 years, there has been interest in elucidating the role of the $-418 \mathrm{G}>\mathrm{C}$ polymorphism in disorders such as head and neck cancer, ${ }^{3}$ breast cancer, ${ }^{2,4}$ generalized aggressive periodontitis, ${ }^{5}$ chronic periodontitis, ${ }^{6}$ chronic cerebrovascular occlusive disease (Moyamoya disease), ${ }^{7}$ and adolescent idiopathic scoliosis. ${ }^{8,9}$
Correspondence: Ana Paula de Souza Department of Morphology, Piracicaba Dental School, State University of Campinas, Limeira Avenue, 90I, Piracicaba 134|4-018,

São Paulo, Brazil

Tel +55 I9 2l06 538 I

Email anapaulapardo@fop.unicamp.br 
The DNA base at position -418 corresponds to the third base of the GAGGCTGGG sequence, the site that binds Sp1, a known transcription factor. ${ }^{27,10}$ The $-418 \mathrm{G}>\mathrm{C}$ polymorphism represents a guanine to cytosine substitution and is not functional in itself; however, it is possible that this polymorphism occurs in linkage disequilibrium with other functional polymorphisms that act to reduce messenger (m)RNA stability, or the translational and transcriptional rates. ${ }^{11}$ Alternatively, this SNP may be functional only as part of a haplotype consisting of several polymorphisms. ${ }^{11}$

Gene polymorphisms have been widely used in association studies of disease susceptibility and, as rare variants $(<5 \%$ frequency), they are most likely to be population-specific. Polymorphisms also represent powerful tools for understanding the evolution of human populations. ${ }^{12}$ The $-418 \mathrm{G}>\mathrm{C}$ polymorphism has been investigated in a chronic periodontal disease association study. ${ }^{6}$ Of all subjects evaluated in the study, the polymorphic $\mathrm{C}$ allele was found only in a single individual, of Japanese ancestry. Interestingly, the presence of the $-418 \mathrm{G}>\mathrm{C}$ polymorphism was associated with some parameters that may contribute to the increase in the risk of cardiac arrhythmias in an Asian population..$^{13}$ This observation triggered our interest in investigating the $-418 \mathrm{G}>\mathrm{C}$ polymorphism in Brazilian and Japanese subjects, as well as in Japanese descendants in southeastern Brazil.

\section{Materials and methods \\ Subjects}

The subject population consisted of 344 unrelated subjects from the State of São Paulo, Brazil. These individuals were recruited from the patient pool of the Dental School, University of Sagrado Coração at Bauru, São Paulo, and from the Brazilian-NIPO Cultural Club of Bauru-SP, and without exclusion criteria. The individuals were separated by ethnicity and subdivided initially into three groups (Brazilian, Japanese, and Japanese descendants). The Japanese group was subdivided into first, second, and third generation and the Japanese descendants into patrilineal ancestry and matrilineal ancestry. The study was approved by the ethics committee for research at the State University of Campinas (protocol 095/97), and an informed consent form was signed by each patient after an explanation of the study had been provided.

\section{Study group distribution \\ Brazilian}

The Brazilian group included 200 subjects aged 30-60 years, of both sexes, born in Brazil, from the State of São Paulo, and without Japanese descent.

\section{Japanese}

The Japanese group included 115 subjects aged 7-80 years, of both sexes, born in Japan and living in Brazil (first generation), or Japanese second and third generation born in São Paulo, Brazil. The subjects born in Brazil, who are children of Japanese subjects born in Japan, were classified as second generation Japanese, and the subjects born in Brazil from second generation Japanese individuals were classified as third generation Japanese.

\section{Japanese descendants}

The Japanese descendant group included 29 subjects aged 4-52 years, of both sexes, born in São Paulo, Brazil, and descendants from intermarriages between Brazilian individuals without Japanese descent and individuals of Japanese ancestry, and could be patrilineal (paternal descent) or matrilineal (maternal descent) ancestry.

\section{Genetic analysis}

Isolation of genomic DNA

Sampling of buccal epithelial cells was performed as described by Trevilatto and Line. ${ }^{14}$ DNA was purified by sequential phenol/chloroform extraction and salt/ethanol precipitation. DNA was dissolved in $70 \mu \mathrm{L}$ of buffer $(10 \mathrm{mM}$ Tris [pH 7.8] and $1 \mathrm{mM}$ EDTA), and its concentration was estimated by measuring the absorbance at $260 \mathrm{~nm}$ using a spectrophotometer. DNA integrity was checked using agarose gel electrophoresis.

\section{Polymerase chain reaction}

A 176 bp fragment of the TIMP2 gene promoter was amplified by polymerase chain reaction with the following primers: forward 5'-GGATCCTGTCAGTTTCTCAA-3' and reverse 5'-TTTCCCCTTCAGCTCGACTCT-3'. Reactions were carried out in a total volume of $50 \mu \mathrm{L}$ containing $500 \mathrm{ng}$ of genomic DNA, $10 \mathrm{mM}$ Tris- $\mathrm{HCl}$ ( $\mathrm{pH} 8.3$ ), $50 \mathrm{mM} \mathrm{KCl}, 1.5 \mathrm{mM}$ $\mathrm{MgCl}_{2}, 1 \mu \mathrm{M}$ of each primer, $200 \mathrm{mM}$ each of deoxyadenosine triphosphate (dATP), deoxyguanosine triphosphate (dGTP), deoxycytidine triphosphate ( $\mathrm{dCTP}$ ), and deoxythymidine triphosphate (dTTP), and four units of Taq DNA polymerase (Amersham Pharmacia Biotech AB, Uppsala, Sweden). The solutions were incubated at $95^{\circ} \mathrm{C}$ for 3 minutes, followed by 35 cycles for 1 minute at $95^{\circ} \mathrm{C}, 1$ minute at $55^{\circ} \mathrm{C}$, and 1 minute at $72^{\circ} \mathrm{C}$, with a final extension of $72^{\circ} \mathrm{C}$ for 7 minutes.

\section{-4 I8G $>$ C SNP genotyping}

The restriction endonuclease digestion was prepared using a $3 \mu \mathrm{L}$ aliquot of the amplified products mixed with $17 \mu \mathrm{L}$ of 
solution containing $2 \mu \mathrm{L}$ of $10 \times \mathrm{New}$ England (NE) buffer (50 mM NaCl, $10 \mathrm{mM}$ Tris- $\mathrm{HCl}, 10 \mathrm{mM} \mathrm{MgCl}, 1 \mathrm{mM}$ dithiothreitol, pH 7.9), 0.5 $\mu \mathrm{L}$ of $\mathrm{HgaI}(2,000 \mathrm{U} / \mathrm{mL})(\mathrm{New}$ England Biolabs Inc, Beverly, MA, USA), and $14.5 \mu \mathrm{L}$ of sterile deionized $\mathrm{H}_{2} \mathrm{O}$. Samples were incubated at $37^{\circ} \mathrm{C}$ overnight. The $\mathrm{C}$ allele completes a corresponding restriction endonuclease site, while the $\mathrm{G}$ allele does not. Endonuclease $H g a \mathrm{I}$ recognizes the polymorphic sequence GACGC and cuts after six nucleotides in two fragments of $109 \mathrm{bp}$ and $68 \mathrm{bp}$. The lengths of the fragments generated after digestion were validated by the NEBcutter version 2.0 program (https:// www.neb.com/tools-and-resources; New England Biolabs Inc., Ipswich, MA, USA). The total amount of the digested product was mixed with $3 \mu \mathrm{L}$ of loading buffer and electrophoresed on a $10 \%$ vertical nondenaturing polyacrylamide gel at $20 \mathrm{~mA}$. The gel was silver-stained with a DNA silver staining kit (Amersham Pharmacia Biotech AB). All samples were genotyped in duplicate and the genotyping was classified as follows: GG (176 bp), GC (176 bp, 109 bp, and $67 \mathrm{bp}$ ), and CC (109 bp and $67 \mathrm{bp})$.

\section{Statistical analysis}

Allelic and genotype frequencies of the $-418 \mathrm{G}>\mathrm{C}$ polymorphism were calculated for all groups. The chi-square test was performed and the odds ratio (OR) and 95\% confidence interval (CI) were also calculated. Differences were considered to be statistically significant at $P \leq 0.05$. An analysis of Hardy-Weinberg equilibrium was used to test the deviation of genotype distribution. Statistical analyses were performed using BioEstat version 5.3 (Belém, Brazil).

Table I Demographic characteristics of the study population

\begin{tabular}{|c|c|c|c|}
\hline & $\begin{array}{l}\text { Japanese } \\
(n=|| 5)\end{array}$ & $\begin{array}{l}\text { Japanese } \\
\text { descendants } \\
(n=29)\end{array}$ & $\begin{array}{l}\text { Brazilian } \\
(n=200)\end{array}$ \\
\hline Age (years) & $60.54 \pm 18.28$ & $22.40 \pm 10.26$ & $43.2 \pm 14.00$ \\
\hline \multicolumn{4}{|l|}{ Sex (\%) } \\
\hline Male & 40 & 48 & 68 \\
\hline Female & 60 & 52 & 32 \\
\hline \multicolumn{4}{|l|}{ Generation } \\
\hline First (\%) & 26 & - & - \\
\hline Second (\%) & 67 & - & - \\
\hline Third (\%) & 7 & - & - \\
\hline \multicolumn{4}{|c|}{ Japanese ancestry (\%) } \\
\hline Patrilineal & - & 72.40 & - \\
\hline Matrilineal & - & 27.60 & - \\
\hline \multicolumn{4}{|c|}{$\begin{array}{l}\text { Notes: First generation indicates a subject born in Japan; second generation } \\
\text { indicates that a subject's mother/father was born in Japan; third generation indicates } \\
\text { that a subject's grandmother/grandfather was born in Japan. Age is given as mean } \pm \\
\text { standard deviation. }\end{array}$} \\
\hline
\end{tabular}

\section{Results}

The demographic characteristics of the study population are summarized in Table 1. There was no evidence of deviation from Hardy-Weinberg equilibrium $(P>0.05$, data not shown).

Table 2 shows the frequencies of the genotypes and alleles of the subjects analyzed. The $\mathrm{C}$ allele was not observed among Brazilian subjects; however, it was found in the Japanese group and in the group of Japanese descendants (18.7\% and $10.3 \%$, respectively, $P<0.001$ ). The homozygous CC genotype was observed only in the Japanese group, and a lower incidence of the homozygous GG genotype was also observed in the Japanese group.

Estimates of the ORs for the genotypic compositions and alleles are shown in Table 3 . Individuals with the $\mathrm{C}$ allele were about 70 times more likely to be Japanese and 41 times more likely to be Japanese descendants than be Brazilian individuals (OR 69.09, 95\% CI 9.35-510, $P=0.0001$, for Japanese; and OR 41.38, 95\% CI 4.80-356.15, $P=0.0001$, for Japanese descendants). The amplicon fragment lengths of the representative genotypes following $\mathrm{HgaI}$ digestion and electrophoresis are shown in Figure 1.

\section{Discussion}

The study reported herein presents an analysis of the TIMP2 $-418 \mathrm{G}>\mathrm{C}$ SNP in Brazilian and Japanese subjects, as well as in Japanese descendants from the southeastern region of Brazil. The $-418 \mathrm{G}>\mathrm{C}$ SNP and four additional polymorphisms in the TIMP2 gene (rs8179090) were analyzed by Furuno et $\mathrm{al}^{15}$ in an association study of Japanese patients with Kawasaki disease. The results suggested that the haplotype containing the $\mathrm{C}$ allele of the $-418 \mathrm{G}>\mathrm{C}$ SNP may be associated with low transcriptional activity of the TIMP2 gene in human monocytes. ${ }^{15}$

Table 2 Distribution of genotypes and alleles of the -4 I8G $>C$ SNP polymorphism in Caucasians, Japanese individuals, and Japanese descendants in southeastern Brazil

\begin{tabular}{|c|c|c|c|c|}
\hline $\begin{array}{l}\text { TIMP2 } \\
-4 \mid 8 G>C\end{array}$ & $\begin{array}{l}\text { Brazilian } \\
(n=200)\end{array}$ & $\begin{array}{l}\text { Japanese } \\
(n=|| 5)\end{array}$ & $\begin{array}{l}\text { Japanese } \\
\text { descendants } \\
(n=29)\end{array}$ & $P$-value \\
\hline \multicolumn{5}{|c|}{ Genotypes (\%) } \\
\hline $\mathrm{CC}$ & 0.0 & 4.3 & 0.0 & \\
\hline GG & 100 & 67.0 & 79.3 & $<0.00 I^{*}$ \\
\hline CG & 0.0 & 28.7 & 20.7 & \\
\hline \multicolumn{5}{|l|}{ Alleles (\%) } \\
\hline C & 0.0 & 18.7 & 10.3 & \\
\hline G & 100 & 81.3 & 89.7 & $<0.00$ I* \\
\hline
\end{tabular}

Notes: $* P<0.05$, statistically significant difference calculated by chi-square test. Abbreviations: SNP, single nucleotide polymorphism; G, guanine; C, cytosine. 
Table 3 Estimate of odds ratios for the TIMP2 single nucleotide polymorphism $(-418 \mathrm{G}>\mathrm{C})$

\begin{tabular}{|c|c|c|}
\hline TIMP2 -4I8G >C & OR & $95 \% \mathrm{Cl}$ \\
\hline \multicolumn{3}{|l|}{ Genotype } \\
\hline \multicolumn{3}{|l|}{ Japanese $\times$ Brazilian } \\
\hline$(C G+C C) \times G G$ & 98.70 & $|3.3|-73 \mid .46$ \\
\hline $\mathrm{CG} \times \mathrm{GG}$ & 85.71 & II.52-637.64 \\
\hline $\mathrm{CC} \times \mathrm{GG}$ & 12.98 & $1.50-112.96$ \\
\hline \multicolumn{3}{|l|}{ Descendant $\times$ Brazilian } \\
\hline$(C G+C C) \times G G$ & 52.17 & $6.01-452.66$ \\
\hline $\mathrm{CG} \times \mathrm{GG}$ & 52.17 & $6.0 I-452.66$ \\
\hline $\mathrm{CC} \times \mathrm{GG}$ & 8.70 & $0.52-143.75$ \\
\hline \multicolumn{3}{|l|}{ Alleles } \\
\hline \multicolumn{3}{|l|}{ Japanese $\times$ Brazilian } \\
\hline$C \times G$ & 69.09 & $9.35-510$ \\
\hline \multicolumn{3}{|l|}{ Descendant $\times$ Brazilian } \\
\hline $\mathrm{C} \times \mathrm{G}$ & 41.38 & $4.80-356.15$ \\
\hline
\end{tabular}

Abbreviations: SNP, single nucleotide polymorphism; OR, odds ratio; $\mathrm{Cl}$, confidence interval; G, guanine; C, cytosine.

The Brazilian population is likely one of the most heterogeneous populations in the world, and includes Native American, African, and European ancestry. ${ }^{16}$ São Paulo state is located in the southeastern region of Brazil, and is known for having the world's largest population of ethnic Japanese outside Japan. The ethnic distribution of residents in São Paulo is $71.8 \%$ Caucasian, $4.2 \%$ African descendants, $22.6 \%$ Mulattos (children of intermarriages between Caucasians and African descendants), and 1.5\% Japanese and Amerindian. ${ }^{17}$ According to Callegari-Jacques and Salzano, ${ }^{18}$ $58 \%$ of the immigrants who arrived in Brazil between 1500 and 1972 were Europeans. European ancestry in Brazilian individuals has been shown in other genetic studies, with individuals from Brazil showing allele frequencies very similar to those of European Caucasian populations. ${ }^{19-21}$ However, the Japanese population has rather limited genetic diversity, according to data from the Japanese Millennium Genome Project. ${ }^{22}$

Population-specific SNPs may have important applications in anthropologic studies, such as studies of population genetic origins. ${ }^{23}$ Genetic analyses of modern populations can offer a more direct approach to recognizing the impact of migration and invasion in historic times, especially when source populations for migration are clearly differentiated from recipient populations. ${ }^{23}$ The present study analyzed the $-418 \mathrm{G}>\mathrm{C}$ polymorphism in three clearly differentiated populations, in particular the Brazilian and Japanese groups. The polymorphic profile observed among these groups was found to be remarkably distinct, given that the $\mathrm{C}$ allele was not observed in the Brazilian group but was present in $18.7 \%$ of the Japanese subjects. In addition, a strong association was found between the $\mathrm{C}$ allele and the Japanese subjects, as well as the CG and CC genotypes and Japanese subjects. The same phenomenon was observed in the Japanese descendant group, although with a lower intensity. Importantly, in all samples containing the $\mathrm{C}$ allele, a fourth band appeared migrating above the $68 \mathrm{bp}$ band. Based on polyacrylamide gels from the patients and analysis using the NEBcutter version 2.0 program, we believe that there are two options to be considered for the fourth band that migrates above the $68 \mathrm{bp}$ band. This band might be a nonspecific one or perhaps derived from the difference in migration of the DNA from the 68 bp band itself. However, it is notable that this band does not change the results of genotyping in patients

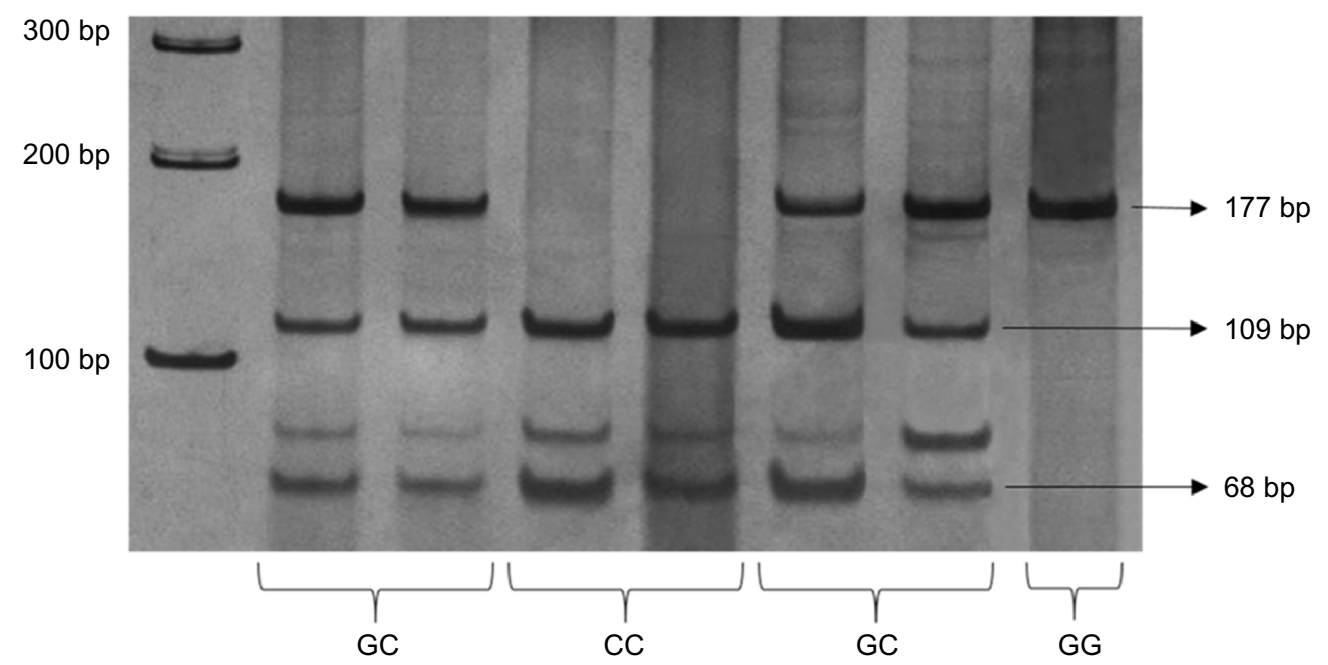

Figure I Restriction fragment length polymorphism-polymerase chain reaction of -4 I8G $>\mathrm{C}$ polymorphism in the promoter region of the TIMP2 gene. The gel illustrates genotypes resulting from digestion with $\mathrm{Hgal}$, ie, GC (177 bp + 109 bp + 68 bp); CC (109 bp + 68 bp) and GG (I77 bp).

Abbreviations: G, guanine; C, cytosine. 
because the enzyme recognizes the polymorphic sequence, GACGC, cleaving into two fragments, both of which are seen in all patients with genotype GC and CC.

Corroborating our findings, the increased frequency of the $\mathrm{C}$ allele is similar to the previous frequency reported in studies of native Japanese (20\%) and Chinese populations $(18 \%) .{ }^{2,4}$ Moreover, Japanese individuals and Japanese descendants showed a markedly increased OR and significant associations $(P<0.05)$, with the exception of the comparison of Japanese descendants and Brazilian subjects for the $\mathrm{CC} \times \mathrm{GG}$ genotypes $(P=0.50)$.

Taken together, these findings suggest a high probability of subjects being Japanese or Japanese descendants if they carry a C allele located in the $-418 \mathrm{G}>\mathrm{C}$ SNP, due to the high frequency known for the $\mathrm{C}$ allele in Japanese individuals and their descendants. In addition to other genetic factors, the $-418 \mathrm{G}>\mathrm{C}$ TIMP 2 polymorphism may be a population marker to assist in predicting Japanese ancestry, both in Japanese individuals and in admixed populations, such as in Brazil.

\section{Acknowledgments}

The authors are especially grateful to the Brazilian-NIPO Cultural Club of Bauru, São Paulo, Brazil. This study was supported by grants from the FAPESP agency in Brazil (grant 04/10399-9 to RAS and grant 03/10422-8).

\section{Disclosure}

The authors report no conflicts of interest in this work.

\section{References}

1. Brookes A. The essence of SNPs. Gene. 1999;234:177-186.

2. Hirano K, Sakamoto T, Uchida Y, et al. Tissue inhibitor of metalloproteinase-2 gene polymorphisms in chronic obstructive pulmonary disease. Eur Respir J. 2001;18:748-752.

3. O-Charoenrat P, Khantapura P. The role of genetic polymorphisms in the promoters of the matrix metalloproteinase- 2 and tissue inhibitor of metalloproteinase-2 genes in head and neck cancer. Oral Oncol. 2006;42:257-267.

4. Zhou Y, Yu C, Miao X, et al. Substantial reduction in risk of breast cancer associated with genetic polymorphisms in the promoters of the matrix metalloproteinase- 2 and tissue inhibitor of metalloproteinase-2 genes. Carcinogenesis. 2004;25:399-404.

5. Chen K, Rajewsky N. Natural selection on human microRNA binding sites inferred from SNP data. Nat Genet. 2006;38:1452-1456.
6. De Souza AP, Trevilatto PC, Scarel-Caminaga RM, De Brito RB Jr, Barros SP, Line SRP. Analysis of the MMP-9 (C-1562 T) and TIMP-2 (G-418C) gene promoter polymorphisms in patients with chronic periodontitis. J Clin Periodontol. 2005;32:207-211.

7. Kang HS, Kim SK, Cho BK, Kim YY, Hwang YS, Wang KC. Single nucleotide polymorphisms of tissue inhibitor of metalloproteinase genes in familial Moyamoya disease. Neurosurgery. 2006;58:1074-1080.

8. Jiang J, Qian B, Mao S, et al. A promoter polymorphism of tissue inhibitor of metalloproteinase-2 gene is associated with severity of thoracic adolescent idiopathic scoliosis. Spine. 2012;37:41-47.

9. Ogura Y, Takahashi Y, Kou I, et al. A replication study for association of 5 single nucleotide polymorphisms with curve progression of adolescent idiopathic scoliosis in Japanese patients. Spine. 2013;38:571-575.

10. Faisst S, Meyer S. Compilation of vertebrate-encoded transcription factors. Nucleic Acids Res. 1992;20:3-26.

11. Hegab AE, Sakamoto T, Uchida Y, et al. Association analysis of tissue inhibitor of metalloproteinase 2 gene polymorphisms with COPD in Egyptians. Respir Med. 2005;99:107-110.

12. Riva A, Kohane IS. SNPper: Retrieval and analysis of human SNPs. Bioinformatics. 2002;18:1681-1685.

13. Lin TH, Chiu HC, Lee YT, et al. The C-allele of tissue inhibitor of metalloproteinases 2 is associated with increased magnitude of QT dispersion prolongation in elderly Chinese - 4-year follow-up study. Clin Chim Acta. 2007;386:87-93.

14. Trevilatto PC, Line SR. Use of buccal epithelial cells for PCR amplification of large DNA fragments. J Forensic Odontostomatol. 2000;18:6-9.

15. Furuno K, Takada H, Yamamoto K, et al. Tissue inhibitor of metalloproteinase 2 and coronary artery lesions in Kawasaki disease. J Pediatr. 2007; 151:155-160.

16. Alves-Silva J, da Silva Santos M, Guimarães PE, et al. The ancestry of Brazilian mtDNA lineages. Am J Hum Genet. 2000;67:444-461.

17. Instituto Brasileiro de Geografia e Estatística (IBGE). Brasil: 500 anos de Povoamento [Brazil: 500 years of Settlement]. Rio de Janeiro: IBGE 2000. Apêndice: Estatísticas de 500 anos de povoamento. p. 226. Portuguese.

18. Callegari-Jacques SM, Salzano FM. [Brazilian Indian/non-Indian interactions and their effects]. Ciência e Cultura. 1999;51:166-174. Portuguese.

19. Scarel-Caminaga RM, Trevilatto PC, Souza AP, Brito RB, Line SR. Frequencies of the $-330(\mathrm{~T} \rightarrow \mathrm{G})$ IL-2 and $-590(\mathrm{~T} \rightarrow \mathrm{C}) \mathrm{IL}-4$ gene polymorphisms in a population from south-eastern Brazil. Eur J Immunogenet. 2002;29:292-296.

20. Vieira AR, Karras JC, Orioli IM, Castilla EE, Murray JC. Genetic origins in a South American clefting population. Clin Genet. 2002;62: $458-463$.

21. Andia DC, de Oliveira NF, Letra AM, Nociti FH Jr, Line SR, de Souza AP. Interleukin-8 gene promoter polymorphism (rs4073) may contribute to chronic periodontitis. J Periodontol. 2011;82:893-899.

22. Haga H, Yamada R, Ohnishi Y, Nakamura Y, Tanaka T. Gene-based SNP discovery as part of the Japanese Millennium Genome Project: identification of 190,562 genetic variations in the human genome. Single-nucleotide polymorphism. J Hum Genet. 2002;7:605-610.

23. Adams SM, Bosch E, Balaresque PL, et al. The genetic legacy of religious diversity and intolerance: paternal lineages of Christians, Jews, and Muslims in the Iberian peninsula. Am J Hum Genet. 2008;83: 725-736.

Advances in Genomics and Genetics

\section{Publish your work in this journal}

Advances in Genomics and Genetics is an international, peer reviewed, open access journal that focuses on new developments in characterizing the human and animal genome and specific gene expressions in health and disease. Particular emphasis will be given to those studies that elucidate genes, biomarkers and targets in the development of new or improved therapeutic

interventions. The journal is characterized by the rapid reporting of reviews, original research, methodologies, technologies and analytics in this subject area. The manuscript management system is completely online and includes a very quick and fair peer-review system. Visit http://www.dovepress.com/ testimonials.php to read real quotes from published authors.

\section{Dovepress}

Submit your manuscript here: http://www.dovepress.com/advances-in-genomics-and-gene-expression-journal 